Situated Interpretations of Nationalism, Imperialism, and Cosmopolitanism Revisiting the Writings of Liang in the Encounter Between Worlds Zhang, Chenchen

Published in:

Journal of Historical Sociology

DOI:

10.1111/johs. 12058

Publication date:

2014

Document version

Peer reviewed version

Citation for published version (APA):

Zhang, C. (2014). Situated Interpretations of Nationalism, Imperialism, and Cosmopolitanism: Revisiting the Writings of Liang in the Encounter Between Worlds. Journal of Historical Sociology, 27(3), 343-360.

https://doi.org/10.1111/johs.12058 


\title{
Situated Interpretations of Nationalism, Imperialism, and Cosmopolitanism: Revisiting the Writings of Liang in the Encounter Between Worlds
}

\author{
CHENCHEN ZHANG*
}

\begin{abstract}
The idea of the nation has been considered to have delivered political modernity from its native Europe to the rest of the world. The same applies, though more implicitly, to those paradoxes inherent to the nationalist ideology that between universalism and national particularity and that between liberal nationalism and imperialism. This article seeks to complicate these theses by looking at the interpretations of nationalism, imperialism, and cosmopolitanism provided by Liang Qichao, one of the most influential Chinese intellectuals in early twentieth century, during his exile in Japan when increasingly exposed to the encounter between worlds. This reading also engages with the wider debates on modernity/modernities in non-Western societies through showing that neither the "consumers of modernity" approach nor the "creative adaptations" approach can be easily applied here. I argue that the various tensions, contingencies and historical situatedness in Liang's accounts of the nation-state structure represent and constitute the paradox of the structure itself. They also shed light on contemporary debates about the limits of our political imagination in the misnamed "global politics" beyond the false opposition between nationalism and cosmopolitanism.
\end{abstract}

$* * * * *$

\section{Introduction}

This article seeks to revisit the political writings of Liang Qichao (1873-1929), one of the most influential "enlightenment" writers ${ }^{1}$ in modern China, on the premise that they bear significant relevance to contemporary debates over modernity, postcoloniality and our political imagination beyond the specific spatial-temporal notion of political community expressed by the nation-state. This revisiting is driven by an observation of the tendency in nationalism studies where universalistic models of nationalism are posited side by side with the persistence of the "incommensurability of cultures" and of "identities" (Sontag 2002:346). This is to

* Chenchen Zhang is an Erasmus Mundus doctoral fellow at the GEM (Globalisation, the EU and Multilateralism) PhD School. E-mail: chenchen.zhang@ulb.ac.be. 
say, researchers either label nationalisms in terms of universalistic models (e.g. "liberal nationalism" versus "non-liberal nationalism", "political nationalism" versus "cultural nationalism", "civic nationalism" versus "ethnic nationalism", and even "Western nationalism" versus "Eastern nationalism"), or get caught into the narrative of cultural identities. Treating Liang's writing on nation and nationalism beyond the framework of "Chinese nationalism" in which it has been usually contextualised ${ }^{2}$, I assume that nationalism, as a "universal model against universalism" (Delannoi 1999:77), is one of the defining components of political modernity, understood here as the conceptual and institutional construction of the territorially defined nation-state as the exclusive mediator between claims of universality and those of difference (Walker 1993). But the way in which nationalism as well as modernity "spreads" from the West to the Rest of the world is much more complicated. Through the case of Liang, I intend to show that neither the "consumer of Western modular nationalism" reading nor the "creative adaptation" reading is adequate. Rather, what we see here is an incoherent mixture of unconscious mistranslation and selective employment of tradition, to which the East-West and/or tradition-modernity dualism cannot be easily applied.

The article first gives a brief overview of the different approaches to modernity in the non-west through the lens of nationalism, with special reference to discussions on "Chinese modernity". It then examines in detail the situated interpretations of nationalism, imperialism and cosmopolitanism offered by Liang during his exile in Japan at the turn of the twentieth century. I argue that while his metaphorical articulation of nationalism as "the beauty of history" unconsciously ignored the ontological analogy between the nation and the individual in modern (i.e. Western) political philosophy of the nation-state, Liang's highly racialised elaboration on "national imperialism" on the other hand exposed and reinforced the paradox between Enlightenment universalism and Romanticist particularism. Finally, I shall examine how Laing's return to (Chinese) cosmopolitanism mirrors contemporary trends of cosmopolitan thought which are, more often than not, still locked in homogenous, solid, nationalist space. This reading shows that a complex web of meanings of different origins arose in Liang's engaging translation of knowledge, instead of a one-dimensional process of "consuming" or consciously creating "difference". It however also discloses certain historical scenarios in which the allegedly universal triumph of the hyphenated nation-state was disturbed and the "secret conflicts between state and nation" (Arendt 1976:230) was never fully reconciled. 


\section{"Consumers of Modernity", "Creative Adaptation" and Multiple Modernities}

This section briefly reviews different approaches to the problem of modernity in the non-West in general, and in East Asia in particular. Although its flaws have now been generally acknowledged and widely discussed, the "consumers of modernity" approach to state development used to be dominant in historical studies of the nonWestern world. It implies a certain perception of modernity as wave-like, flowing from Western Europe to the rest of the world. Countries/nations could be hence ranked according to their position on this single, directed wave. From this perspective, the modern history of East Asia, as the title of a representative work from the 1960s indicates, is nothing more than "A History of the Western impact and the Eastern Response" (Clyde and Beers 1966). The seemingly natural logic is that through the response of the local elites of non-Western countries to the wave of modernisation, the model of (Western) nation-state could be transplanted, successfully or not, to these other parts of the world. The rise and expansion of the Japanese empire used to be narrated as a successful transplantation of Western modernity, with its destruction also making explicit the unresolvable contradictions of Western imperialism. A standard modernising history of Japan within this approach would be one that starts with a resolute rupture from the past, both in temporal and spatial terms, as read from the popular Datsu-A Ron (discourse on de-Asianisation) in the late nineteenth century.

Concerning the "spread" of modern nationalism, although more sophisticated stories were told by Anderson about nationalism in Europe, America and elsewhere (Anderson 2006), postcolonialist scholars such as Chatterjee would argue that the underlying logic seems to remain that nationalisms in the Rest "have to choose their imagined community from certain 'modular' forms" made ready for them by Europeans and Americans. In short, non-Western populations - in light of the "first in Europe, then elsewhere" rule Chakrabarty has spoken of (2000:7) - can only be "perpetual consumers of modernity" (Chatterjee 1993:5).

The "creative adaption" approach therefore enunciates the "call to difference" (Taylor 1997:44) felt by modernizing nationalist elites in the non-West. Taylor contends that in responding to the encounters with the West, the local elites felt the need to do more than merely what has been done - the modular already made available - in the West. This leads to, in the words of Taylor, a creative adaptation drawn on the cultural resources of their tradition. The creative adaptations accordingly have to be "different from culture to culture" (ibid.). This argument resembles Chaterjee's critique on Anderson 
that "the most creative results" of nationalisms in Asia and Africa are posited on "a difference with the 'modular' forms of the national society propagated by the modern West" (Chatterjee 1993:5, his italics).

The task thus is to explore how differences are made. One way could be, according to Chatterjee's observation on the Indian case, dividing the world of social institutions into the material domain and the spiritual one (1993:9). Similarly, this strategy was also prevalent among those earliest reformers in China, as they named the two domains "yong" (practical application) and "ti" (fundamental principles) ${ }^{3}$. But the recognition of this formula among Chinese intellectuals was drawing to an end by the time of the First Sino-Japanese War. The humiliating defeat forced them to doubt the validity and the value of their "fundamental principles", and embrace the Western ideas with body and soul. This is indeed what Liang Qichao, and many of his contemporaries, mainly argued for after the failed Hundred Days' Reform in 1898. What if even the spiritual domain is no longer maintainable vis-à-vis Western civilisation? It is on this account that Levenson poses the dilemma and dichotomy of "history and value" in modern Chinese history: the conflict between what is "true" and what is "mine" entails the following: be Chinese and pre-modern, or be modern and no longer Chinese. Even though in his comprehensive studies of Liang, Levenson has noticed the way in which Liang attempted to replace the opposition between the West and China with the opposition between the "modernized" and the "unmodernized" - that is to say, when speaking of parliamentarianism, a claim is made that "there is no Western parliamentarianism; there are only parliaments in the West", and China needs only "institute one herself" (Levenson 1959:127); what is presented here is still, as Dirlik comments on "the modernizationist perspective of historians", "manifestations of a Chinese inability to liberate themselves from the burden of a weighty past". Yet from an alternative perspective, these struggles may appear as "the very contradictions of a Chinese modernism" (Dirlik 2005), or of modernity in China.

Going back to Leveson's discussion (through Liang) on parliamentarianism, what if China has indeed managed to institute a parliament that is even better the Western ones? What if one has managed to discovered a parliamentary spirit in the thousands of canonical books that are genuinely Chinese? The problem is exactly the same one as informed by recent critiques on multiple modernities: that the West "remains the point of reference", and that it remains unquestioned "the assumption of internal civilizational dynamics that developed in isolation until the point of contact with Western modernity" (Bhambra 2007:65) - so that one can articulate difference/particularity through identifying a parliamentary spirit 
in the internal universe of Chinese culture. Social sciences and humanities have witnessed the rise of various forms of pluralising modernity - such as possible, alternative or multiple modernities (see Eisenstadt 1999; Mitchell 2000; Taylor 2001) - from the 1990s onwards, yet many of the developments in this direction are not radically transformative as they seem like to be. As Thomassen notes, one of the leading strands in the studies of multiple modernities - the historical-comparative studies of civilisations by Eisenstadt "stayed within a Weberian comparative method and analytical framework" (Thomassen 2010:328). In a way, the method of multiple modernities has been further developed but not substantially moved beyond the motif of "creative adaptation". If staying with the assumption that an original Western modernity is adapted differently "from culture to culture", the irony is turned into destiny: that the demand for difference must be based on the fact that they have accepted the West as the universal.

It is within these wider debates that this specific reading of Liang is situated. It intends not to find out how Liang's writing on nationalism accords to or deviates from a Western model of nationalism; nor does it focus on the moments of traditional culture that may contribute to creative adaptations. Rather, it assumes that nationalism, or the alliance and tension between the nation and the state must be contextualised within the global conditions of the desire for particularity' (Duara 2002:97), and explores under these conditions how knowledge of nation, empire and cosmopolis is produced, mediated and manifested in this historical conjuncture.

\section{History and Mind: Nationalism as "The Beauty of History"}

It might be useful to give a short note on Liang's intellectual life for general readers. During the 1890s, Liang was best known as a disciple of Kang Youwei, a prominent scholar in Confucius classics and a supporter of constitutional monarchy based on Confucian justification. Under Kang's overwhelming influence, Liang had sought to synchronize classical Confucian sanctions with "Western values" by taking Kang's approach of examining the authenticity of the Confucian classics, an approach severely criticized by himself some years later. Liang was forced into exile to Japan in 1899 following the failure of the Hundred Days' Reform, and this started a period in which both Liang's fame and his intellectual creativity reached their zenith. The main reason could be that Japan provided him with an ideal environment where he could commit himself to absorbing and introducing modern western scholarship. He would soon find a treasure of modern concepts in the rapidly changing Japanese vocabulary, which include guojia ( $\mathrm{J}$ : kokka; the state), 
guomin/minzu (J: kokumin/minzoku; the nation, or the citizenry), lishi (J: rekishi; history), and zhuquan (J: shuken; sovereignty). Japanese sinologist Kagami Mitsuyuki considers Liang to be the first one to use the term "minzu" in Chinese literature, and the first to connected the concept of China with that of the nation - through the term "zhongguo minzu" in 1901 and "zhonghua minzu" (both meaning Chinese nation) in 1902 (Kagami 2008:16). Liang”s thinking is thought to be characterised by continuous changes to fit the dramatically changing political and intellectual climate in his time. However, some researchers also take these strategic changes themselves as "persistent unity" beneath them (Levenson 1959).

Before introducing Liang's interpretation of nationalism, let us first take a glance at his presentation to his readers (many of whom were Chinese revolutionaries in exile in Japan) of a new view of world history. This linear, evolutionary and progressive view of world history has now turned into a universally accepted myth ${ }^{4}$, but in his time it was a true revolution - as Liang himself literally claimed, to make a revolution in China, one must make a revolution in history studies $^{5}$. Thus he drew an ambitious outline of what he called "New Historiography" in 1902. This work began with a criticism of traditional Chinese historiography, while admitting that history was the only discipline which had developed for thousands of years in China in comparison to all the prevalent disciplines in Europe at the time. Liang claimed at the very beginning, "History is the broadest and most vital discipline of all knowledge. It is the mirror reflecting the nation; it is also the source of patriotism. For the facts that nationalism is flourishing in today's Europe and that all the countries there are making daily progress toward civilisation, history writing proudly claims a great responsibility." (Liang 2001: 1628) The glowing praise for the function of history writing may indicate that the following discussion would focus on the project of a national history, since the primary role of history study was to bring prosperity to the nation. Yet the logic of the "New Historiography" was that the national narrative became possible only when the imagination and construction of global history emerged out of teleological universalism.

This essay mainly developed a step-by-step approach to redefining history. In the last and most important part of it, Liang finally reached a complete definition of history, which is "the narrative of the development of human races and the competition among them" (2001: 1634). It is true that this version of world history was "not only written as an account of the European, and especially, Aryan, conquest of the world, it is also written from the European perspective of conquest and the bringing of enlightenment to the world" (Duara 1995: 33). However, we have to notice that here the consciousness of world history and especially of the relationship 
between history and the nation was also reconfigured in the very process of translation, both metaphorically and practically, when different shades of meaning from both foreign and "traditional" ideas were blended with one another and became deviating from the original "source".

At first glance, this text clearly revealed how eagerly and unquestionably Liang, like many of his contemporaries, accepted the evolutionary and race-oriented idea of world history. They all rejected the old, so-called "twenty-four dynastic" histories as non-history, or history of slavery ${ }^{6}$, and instead sought to retell the story of the twenty-four dynasties as national history in the fashion of Enlightenment narrative ${ }^{7}$. Yet in this reading, in Hegelian terms, history had nothing to do with the "consciousness of freedom". The deviation lay in the fact that in Liang's new history, the development of world history was not paralleled by the very notion of "idea"; On the contrary, the idea belonged to a category in opposition to the category of history ${ }^{8}$. Evolutionary history was a useful tool situated in certain historical conjunctures, rather than an abstract concept - it must be fully understood at this particular moment, because it was a matter of survival. Beyond this practical concern, Liang retained the realm of idea, or ethics, to be realised in the future.

In another highly relevant essay entitled "on the similarities and differences between changes of the idea of the state" (1901), Liang illustrated the changes of the idea of the state via the following diagram (2001: 765):

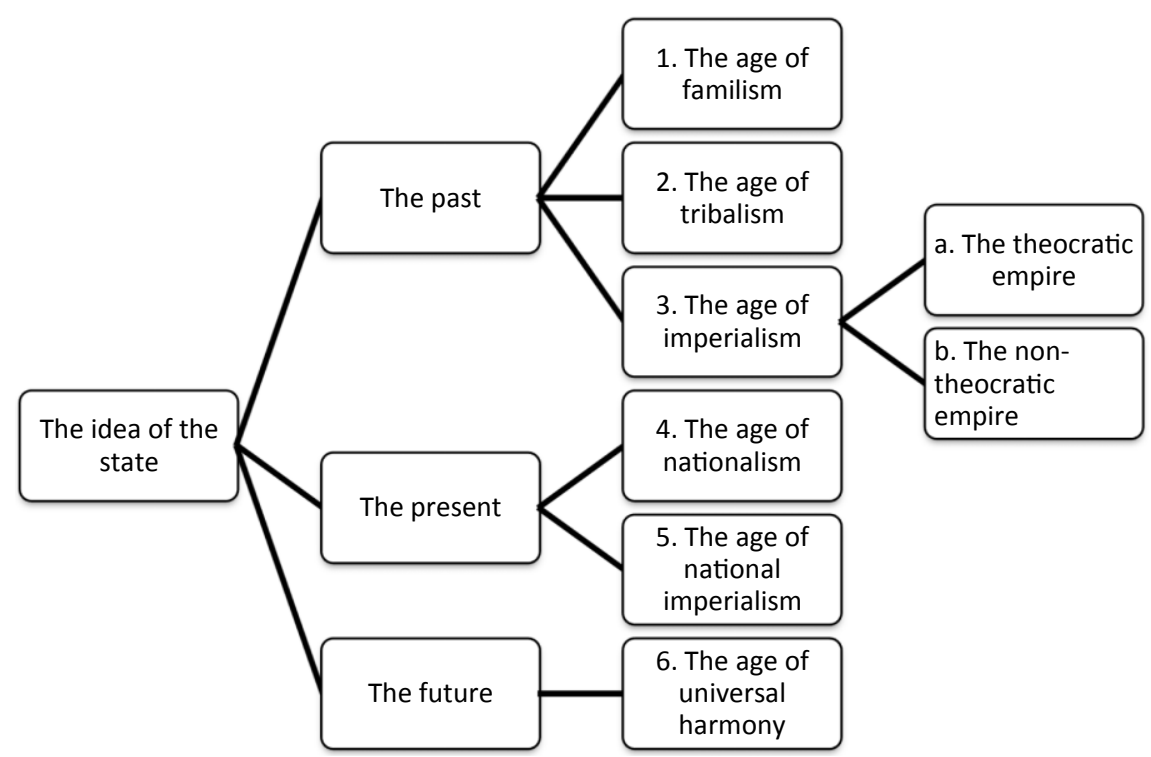


He then concluded that within the present order, Europe and North America were in the age of nationalism and national imperialism in parallel, whereas Asia was in the age of ancient imperialism and nationalism. To be more realistic, the present world was no more than a stage in which only nationalism and national imperialism played their roles. Nationalism, as understood by Liang, was derived from the idea that a legitimate state must be founded by the consent of the people, and accordingly the people have unlimited sovereignty and the government cannot go against the people's will ${ }^{9}$. He laid great emphasis on the leading role of nationalism in recent European history, which he believed "has benefited from nothing so much as from nationalism." (2001: 766) In other words, the utmost significance of nationalism was, for Liang, that it had served both as the cause of and as the impetus to the progress of Europe. And that nationalism must be transplanted into China since it was the key to gaining a position on the ladder of progress.

In an intriguing passage on the difference between the "world" and the "state", Liang wrote: "Scholars of today are not unaware of the beauty of this doctrine (cosmopolitanism), but viewing it as the beauty of mind, not the beauty of history. Therefore, it is the state, not the world that is taken as the highest group" (2001:557). Through placing mind in opposition to history, he in fact named nationalism "the beauty of history", in contrast to cosmopolitanism as "the beauty of mind". That is to say, nationalism was conceived as a necessary phase in modern history and also as a powerful means to entering into World History. Although Liang definitely tried to reformulate the former empire to be a modern polity that binds the imagined community of the nation and the political entity of the state, this reformulation, just as his acceptance of the seemingly Hegelian narrative of world history, was a practical matter about survival rather than a conceptual one. What was absent in this understanding was the notion of the nation, or the hyphenated nation-state, as the mediator of absolute individualism and the universalistic principle of humanity. There was indeed, as Levenson talentedly remarks, a conflict between history and value. But the signified is not as he says - namely the Chinese was history, was mine; and the Western was the value, was true. On the contrary, the value was in China, but History was in the West. To preserve the value, the nation must be conquered by the state and get onto the historical stages of nationalism, and then national imperialism.

\section{Nationalism and National Imperialism}

The essay published by Liang in 1903 introducing the Staatswissenschaft of Bluntschliis generally viewed as marking the 
transformation of his political position from liberalism to statism. ${ }^{10}$ He famously declared in this essay that "China's most urgent need is organic unity and powerful order, and liberty and equality are secondary" (2001: 450). On the surface, the reason for this transformation can to be taken to be the expansion of imperial powers across the world and especially the failure of the Boer and Filipino struggles he had witnessed. But curiously enough, his attitude toward imperialism was rather ambiguous. Obviously he maintained that the increasing political and economic penetration of the colonies or semi-colonies by Euro-Americans sounded great alarm to China ${ }^{11}$. In this sense, nationalism, which he urged China to "practice" undoubtedly, served the purpose of fighting the foreign power off; it was the synonym of anti-imperialism. ${ }^{12}$ But in his vision of global history, "the age of nationalism" and "the age of national imperialism" appeared as two successive stages where one inevitably led to another.

This conviction, that nationalism and imperialism are ranked on the ladder of progress in an invariable sequence, and the movement from one stage to another is an irreversible historical course, had two implications. One was that China had to first step onto the stage of nationalism before entering the next stage, the other being that the ultimate goal of China would be, and should be, to reach the stage of imperialism. He also noticed the fundamental distinctions between imperialism of the nineteenth century and that before the eighteenth century. The latter, according to Liang, was derived from the empire of the monarch; whereas the former from the empire of the whole nation. Drawing a problematic analogy between a state and a human being, he suggested that nationalism is an indispensable element for a state to develop from "an embryo" to a full-fledged and autonomous organism. In other words, a state cannot be called a state, just like a person cannot be called a person if it remains in the state of embryonism, unless it had already moved through the stage of nationalism. And the progress from nationalism to imperialism was an achievement to accomplish after the child becomes an adult (2001: 767). Therefore, he had not changed his opinion until 1903 that placing state interests and strong government over interests of the people should not be applied to today's China, even though it was then prevailing in the West - since China had never gone through the nationalist stage, she was not qualified as a state, or a person, yet. This metaphor of the historical development of a state as the natural growth of a human being may easily remind us of the way in which Liang interpreted the conception of civilisation: "to be a nation was to be civilised, and vice versa" (Duara 2004: 91). Now he went one step further and pointed out that to be a national empire was to be more 
civilised. At the heart of these accounts was the belief that while imperial expansion is the greatest cause of the crisis in China; their conquest is, from many aspects, a civilising mission.

Liang's perception of imperialism as an advanced stage in linear history was also affected by the confrontation of Westerners and Japanese in China after the Sino-Japanese War in 1895. After all, "Japan was not just another imperialist; it was an Asian imperialist" (Iriye 1970:143). For some writers like Liang, Japan was simply following trends in Europe; whereas for others like Sun Yat-sen, the rise of Japanese imperialism harboured the possibility that China might seek alliance with Japan against the West. Moreover, even for Liang, the way in which he employed imperialist discourse to interpret and predict Chinese history was predicated upon an unquestioning acceptance of Japanese Orientalism and Asianism. As is well known, the Japanese began to replace the word chügoku (literally "middle kingdom", as in Chinese) with shina, which was a transliteration of the English word China, to refer to China. Through this replacement, as Stephan Tanaka puts it, "Japanese were using the West and Asia as other(s) to construct their own sense of a Japanese nation as modern and oriental" (1993: 18). Liang, always claiming that Japanese books were an efficient and primary shortcut to Western Knowledge, unsurprisingly followed this usage in his early works of the exile period. He began to call China "zhina" (the Chinese pronunciation of the same two characters in the word shina) and call the Chinese "zhina-ren" (people of zhina).

This process of self-Orientalisation was reinforced by the discourse on Asia as a geographical space in which China should be located. While being a geographical space and a concept invented by the Westerners, Yazhou (or Ajia in Japanese) had now enthusiastically embraced by both Chinese and Japanese politicians as well as intellectuals, for "it provided them with a new concept with which a new and yet contentious relationship was created" (Chow 2001:67). The referent was a spatial imaginary in which the leading role of China could be reestablished, - as was put by Liang, "Asia is China's world, just like the World is Europe's." It was through the reconfiguration of the spatial concept of Asia that Liang gained access to the genealogy of imperialist discourse.

As Duara indicates in his work on the history of Manchukuo, our current view of nationalism and imperialism as two very different phenomena - that one is characterised by "citizenship, equality and development" while the other by "domination, exploitation and the reproduction of difference between ruler and ruled in the colonies" (Duara 2004:9) - did not come into being until very recently. Even though nationalism by now is no longer seen as related to citizenship and equality in many observers' view, it has been considered 
as an essential factor in the development of liberal states up until the end of the Second World War. During the nineteenth century, however, the two concepts could hardly be disentangled in the imperial expansion, which were also regarded as national projects - of a few major powers. Here Liang's treating of imperialism as a historical successor to nationalism must be put into the context of the inextricable link between Enlightenment universalism and Romantic particularism which is often raised in discussion nationalism(s) in the West. The opposition between the two is taken as a fundamental one by Isaiah Berlin, who sees the transition from the Enlightenment to Romanticism as "the greatest single shift in the consciousness of the West that has occurred", and having cracked "the backbone of European thought" (Berlin 1999:1). Hence the divide between civic nationalism and ethnic nationalism is still an important component of the standard theory of nationalism.

But this divide or transition has been interrogated and made complicated from different perspectives. Delannoi regards the French Revolution as realising the combination of "applying the Enlightenment rationale and expressing the Romantic soul (Delannoi 1999:68), and Eagleton comments with remarkable insight on the mutual construction of the politics of difference or specificity and the Enlightenment claim of universal rights and abstract equality (Eagleton 1990:30) ${ }^{13}$. The paradox between the particular and the universal in nationalist ideology also puts two other concepts into question: imperialism and cosmopolitanism. At one end, cosmopolitanism embraces a universalistic view of world history while being locked into a state-oriented mode of global space" (Campbell \& Shapiro 1999: xii); At the other end, based on missionary and racist ideologies, modern imperialism simultaneously reinforces and challenges the ideal model of the nation-state. Therefore it is always a disturbing question for liberal historians of nationalism, as Balibar suggests, that one cannot convincingly explain "where and when does the transition from 'liberal nationalism' to 'imperialist nationalism' occur" (Balibar 1991: 65).

What are the implications of Liang's intuitive and superficial understanding of the links between nationalism and imperialism for our task of rethinking the modern? Taking the West as the point of reference, it highlights the paradox in the ideal of liberal nation state on one hand, and shows the so-called inherent contradictoriness in the nationalist thinking of indigenous elites on the other. That is, in order to challenge the imperial structure, they must share the same system of doctrines with those whose rule they challenged in the first place. ${ }^{14}$ But this is only half of the story - if we no longer take Western modular nationalism as the only framework of analysis, it is intriguing to see that the abovemen- 
tioned ethical question for "liberal historians of nationalism" is cancelled out. Liang did recognise the inextricable connection between nationalism and imperialism in his time as contemporary critical historians do, but he never criticised such a connection. This surely has to do with the spatial and temporal limitations to which every writer or thinker is bound. But more importantly, there is no need for criticising it or trying to answer the question for liberal nationalists, as Liang held an essentially instrumental perception of the nation and the nation-state. As said earlier, the ontological analogy between the sovereign state and the autonomous individual is absent in this understanding. These discourses on the historical course of the state on the one hand surely would not emerge without the encounters between worlds; but on the other hand, as the problematic of the modern is always of "global dimensions", they should be considered more than "the cultural variants of an original European modernity", but a constituent of the "multiple co-presences of modernity" (Bhambra 2007:71).

\section{The "Return" to Cosmopolitanism}

In his late years, especially after the First World War, Liang once again allegedly changed his mind and this time he was considered to revert to Chinese tradition, of which a crucial element was, as he believed, cosmopolitanism. Late in his life he wrote briefly on cosmopolitanism and traditional Chinese thought: "[W]e Chinese people have never recognised the nation as the highest group, instead, we maintain that there must be a higher group sovereign over all the nations, which is called tianxia (under Heaven).... Take the peace and happiness of mankind as a whole, rather than of a single nation, as the aim and end. Such kind of philanthropic cosmopolitanism has been, to be sure, the core of our political theories for thousands of years." (2005: 733-34) When he was advocating nationalism, he powerfully argued that "the commonly accepted idea" was "the nation, instead of the world, is the highest group" among all groups of human society. But by 1923 his argument was completely reversed: "Chinese people have never identified the nation as the highest group of the human being since the beginning of their civilisation. Their political theory is meant for all mankind; accordingly it aims at keeping the peace of all-underheaven (ping tianxia). The nation is merely a stage, along with the family, towards the tianxia." (1998: 5)

Thus ironically, in claiming that cosmopolitanism, or, rather, a view of China-centred universalism was at the heart of traditional Chinese philosophy, Liang's argument ended up regarding universalism as an essential dimension of the national character of China, 
or, Chineseness. But the effort to prove that Chinese universalism (as paradoxical as the term itself reveals) as an attribute of nationality had existed throughout history was only meant to manifest its particularity. For some, this irony implies a transition from a China as the world, when cosmopolitanism, in the face of Confucianism, not only informed the intellectuals but also "correspond to the day-to-day life in rural China", to a China provincialising herself to become a nation, hence cosmopolitanism becoming one defining feature of her cultural identity (Levenson 1971:5). Is it not the presumption of this interpretation that the cosmopolitanism as informed by Zeno and Kant ${ }^{15}$ is a cosmopolitanism without adjective, one that needs not to be mediated by any particularity, and hence cosmopolitanism as such?

Similar concerns have been raised around the current revival of the academic interests in cosmopolitanism as one characteristic of "European identity" (e.g. Delanty \& Rumford 2005; Rumford 2007). Scholars question the "Europeanness" of cosmopolitanism through reflecting upon its historical configurations: how they are drawn upon the ambiguous portraits of the rootless, the outsider and the colonial other (Kofman 2005; Levy \& Sznaider 2007). In particular, Honig sets out to test the ontological paradox of cosmopolitan thinking in her critique of "rooted and affective" cosmopolitanism proposed by Kristeva. By making its way through France, through "the national spirit as esprit general reached by the French Enlightenment" (Kristeva 1993:60), this cosmopolitanism works to "shore up a uniquely French identity, even while claiming to overcome or transcend it" (Honig 1998:204). Thus highlighting the differences between Chinese, European and French versions of cosmopolitanism, or distinguishing between tianxia and cosmopolis, does little to acknowledge and explore the paradoxical entanglement of nationalism and cosmopolitanism. In these narratives, essentialist understandings of culture remain largely unchallenged - wherein the Other is certainly welcome, yet at the same time is considered as ethically obliged to reaffirm and enrich existing categories such as culture and the nation.

\section{Conclusion}

In formulating the "very contradictions" of Chinese modernism, Dirlik writes:

Enlightenment at once as a means of liberation from the past and a negation of native subjectivity and learning; the past at once as a source of identity and a burden on the present; the individual at once as citizen of a modern nation and a threat to collective national liberation; ... the nation at once as an agent of cosmopolitan universalism and a defence against hegemony that closes out the 
world in perpetuation of native parochialism. The contradictions could be multiplied endlessly. (2005: 117)

It seems both unnecessary and undesirable to clarify which contradictions are generalisable and which are not. The contradictions of modernity may contain at once commonality and distinctiveness, shared problematic and contingent traces. Truly it was "modernity that invented one world out of the many worlds" (Dirlik 2008:20), but from this also follows that it must be a conscious labour to re-account for the many worlds, not only before and after but also accompanying, the invention of modernity.

The themes I have explored in this article are essentially modern. They concern the spatial and temporal solution and imaginary of political community expressed by the nation-state structure, "solidly held together by a mostly mythical, yet rarely politically challenged or theoretically problematized hyphen" (Lapid 2001: 24). I have shown various tensions, contingencies and historical situatedness in Liang's interpretations of this solution, which indeed constitute the contingency and processuality of the solution itself. While the state appeared as hegemonic actuality, the nation was going to claim its ultimate ethical authority in some yet-tocome world without nations.

If we are, as many are convinced, living in an age in which "all three components of the nation-state (the nation, the state, and the hyphen)" (Lapid 2001: 24) are undergoing profound reconfigurations, it is not without benefit that we consider the present through looking back at the past. The historical scenarios revisited here show and contain the paradox of the hegemonic structure of the nation-state in a certain context and hence shed light on contemporary debates about the limits of our political imagination in the misnamed arena of "global politics"- which in fact refers to politics between and within states. Indeed, as this essay has shown, one has to develop a better understanding of the historical and conceptual roots nationalism and cosmopolitanism have in common in order to move beyond the false opposition between them.

\section{Acknowledgement}

The author would like to thank Naoshi Yamawaki, Yujiro Murata and Viren Murthy for their advice and support during her study at the University of Tokyo, when the initial form of this paper was conceived. She is also grateful to Gurminder Bhambra, other participants of the conference "Rethinking the Modern" held in July 2011, Birmingham, and the two anonymous reviewers for their valuable comments. 


\section{Notes}

${ }^{1}$ Evidences could be found both in history and in the academic discourses. People such as Mao Zedong and Hu Shi frankly spoke of the great influence Liang had made on them, even though they themselves held different political opinions. Duara in his well-known Rescuing History from the Nation depicted Liang as "the first to write the history of China in the narrative of the Enlightenment" (1995:33).

${ }^{2}$ See for instance Bastid-Bruguière (2004); Murata (1996); Zhao (2004).

3 The well-known slogan invented by the eminent official during the late Qing Dynasty Zhang Zhidong said: Chinese learning for fundamental principles and Western learning for practical application (Zhongxue weiti, xixue weiyong).

${ }^{4}$ This could be seen from many fierce criticisms about Fukuyama's the "end of history" thesis. In a sense, these wide-spread, effortless attacks on Fukuyama's argument are only to prove that his premise has been universally accepted.

5 Chatterjee has also shown us a parallel theme in his study of Bankim. He notes that "the historical consciousness he (Bankim) is seeking to invoke is in no way an 'indigenous' consciousness, because the preferred discursive form of his historiography is modern European"(Chatterjee 1993:77).

${ }^{6}$ Zou Rong (1885-1905), in his widely known and stimulating text Geming Jun (Revolutionary Amy, first published in 1903 in Shanghai), echoed Liang in an even more radical way, "the Chinese do not have history. The so-called Twenty-four Dynastic Histories in China are but a huge history of slavery. As slaves, the Chinese could not have a history of their own making”. (Zou [1903]1956:353)

7 It is interesting to consider a classic example of "cosmopolitan history" - the Essai sur les moeurs et l'esprit des nations et sur les principaux faits de l'histoire depuis Charlemagne jusqu'à Louis XIII by Voltaire. The book outlines a "cosmopolitan history" that starts "with France poised to undergo a great expansion of national spirit in the age of Louis XIV" in its European portion, and closes with "the rejection of Christianity by China and Japan" in its non-Western part (O'Brien 1997:50).

${ }^{8}$ In the Hegelian scheme, to borrow Engels's words, "However abstract and idealist the form employed, the development of his ideas runs always parallel to the development of world history, and the latter is indeed supposed to be only the proof of the former" (Engels, quoted in Harvey 2001:296)

${ }^{9} \mathrm{He}$ also examined the theoretical sources of the two according to his rather limited reading of European literature: the theory of popular sovereignty represented by Rousseau and the theory of "the right of the strongest" by Spencer.

10 Zhengzhixue dajia bolunzhili zhi xueshuo (on the teachings of the great politikwissenschaftler Bluntschli), in Liang (2001: 449-462).

${ }^{11}$ In an essay entitled "Mieguo xinfa lun" (on the new rules for destroying countries, 1901), Liang gave an in-depth analysis of what he saw as a new "pattern" of destruction that had revealed itself in Poland, India, Philippines, Egypt and many other countries controlled by imperial power. Noting that economic infiltration into native structures was efficient enough to destroy a country, he wrote: "To those who claim that opening 
mining, railroad, and concessionary rights to foreigners is not harmful to the sovereignty of the whole, I advise you to read the history of the Boer War." (2001: 726)

${ }^{12}$ Levenson formulates such kind of perception of nationalism as follows: "It is interpreted in the beginning as organised resentment, a device to make Chinese close ranks and resist enslavement; in the end, it is the spirit which moves a people to take non-traditional measures to implement resentment." (1959:113)

${ }^{13}$ See also Seth on the paradox between ethical universalism and political particularism in the Revolution: "Was not Anacharsis Cloots more in tune with the universalistic ethic of the French Revolution when he championed a revolutionary war that would unite the 'entire human family' in a single republic, under the banner of liberty, with Paris as the capital of the globe?" (1995:43) Regarding the Romanticism side, see Meinecke (1970) and Balibar (1994) on the complicated relationship between "ethnic nationalism" and cosmopolitanism in Fichte.

${ }^{14}$ To quote Chatterjee again, nationalist thinking in the colony reasons "within a framework of knowledge whose representational structure corresponds to the very structure of power nationalist thought seeks to repudiate" (1986: 38-39).

${ }^{15}$ Modern advocates of cosmopolitanism trace the source of such a trend of political or philosophical thought to the ancient time. Fine and Cohen, for example, elaborate four "moments" of cosmopolitanism in the history of Western political thought: Zeno's moment in ancient Greece, Kant's moment in the Enlightenment, Arendt's in post-totalitarian thought and Nussbaum's in late North American thought (Fine \& Cohen 2002).

\section{Reference}

Anderson, B. (2006). Imagined Communities: Reflections on the Origin and Spread of Nationalism. London: Verso.

Arendt, H. (1976). The Origins of Totalitarianism. New York: Harcourt Brace Jovanovich.

Balibar, E. (1991). Racism and Nationalism. In E. Balibar \& I. Wallerstein, Race, Nation, Class: Ambiguous Identities (pp. 37-67). London: Verso, 1991.

- (1994). Fichte and the Internal Border: On Addresses to the German Nation. In E. Balibar, Masses, classes, ideas: Studies on politics and philosophy before and after Marx (pp. 61-84). London: Routledge.

Bastid-Bruguière, M. (2004). The Japanese-Induced German Connection of Modern Chinese Ideas of the State: Liang Qichao and the Guojia lun of J. K. Bluntschli. In J. A. Fogel (Ed.), The Role of Japan in Liang Qichao's Introduction of Modern Western Civilization to China (pp. 105124). Berkeley: Center for Chinese Studies, Institute of East Asian Studies, University of California.

Berlin, I. (1999). The Roots of Romanticism. Princeton N.J.: Princeton University Press.

Bhambra, G. (2007). Multiple Modernities or Global Interconnections: Understanding the Global Post the Colonial. In N. Karagiannis \& P. Wagner (Eds.), Varieties of world-making: beyond Globalization (pp. 59-73). Liverpool: Liverpool University Press.

Campbell, D. \& Shapiro M. (1999). Introduction: from ethical theory to the ethical relation. In D. Campbell \& M. Shapiro (Ed.), Moral spaces: 
rethinking ethics and world politics (pp. vii-xx). Minneapolis; London: University of Minnesota Press.

Chakrabarty, D. (2000). Provincializing Europe: Postcolonial thought and historical difference. Princeton, N.J: Princeton University Press.

Chatterjee, P. (1986). Nationalist Thought and the Colonial World: a Derivative Discourse? London: Zed Books for the United Nations University.

- (1993). The Nation and its Fragments: Colonial and Postcolonial Histories. Princeton N.J.: Princeton University Press.

Chow, K. (2001). Narrating Nation, Race, and National Culture: Imagining the Hanzu Identity in Modern China. In K. Chow et al. (Ed.), Constructing Nationhood in Modern East Asia (pp. 47-84). Ann Arbor: University of Michigan Press.

Clyde, P. H., \& Beers, B. F. (1966). The Far East: a history of the Western impact and the Eastern response (1830-1965), 4th ed. Englewood Cliffs, N.J.: Prentice-Hall.

Delannoi, G. (1999). Sociologie de la nation: Fondements théoriques et expériences historiques. Paris: A. Colin.

Delanty, G., \& Rumford, C. (2005). Rethinking Europe: Social theory and the implications of Europeanization. London: Routledge.

Dirlik, A. (2005). Marxism in the Chinese revolution. Lanham: Rowman \& Littlefield.

- (2008). "Timespace, Social Space, and the Question of Chinese Culture". Boundary 2. 35 (1): 1-22.

Duara, P. (1995). Rescuing History from the Nation: Questioning Narratives of Modern China. Chicago: University of Chicago Press.

. (2002). Civilizations and Nations in a globalizing world. In D. Sachsenmaier \& J. Riedel (Eds.), Reflections on multiple modernities: European, Chinese and other interpretations (pp. 79-99). Leiden: BRILL.

- (2004). Sovereignty and Authenticity: Manchukuo and the East Asian Modern. Lanham, Md.: Rowman \& Littlefield.

Eagleton, T. (1990). Nationalism: Irony and Commitment. In T. Eagleton et al., Nationalism, colonialism, and literature (pp. 23-42). Minneapolis: University of Minnesota Press.

Eisenstadt, S. N. (1999). Multiple modernities in an age of globalization. Canadian Journal of Sociology 24(2): 283-95.

Fine, R., \& Cohen, R. (2002). Four cosmopolitanism moments. In S. Vertovec \& R. Cohen (Eds.), Concieving cosmopolitanism (pp. 137-164). Oxford: Oxford University Press.

Harvey, D. (2001). Spaces of Capital: Towards a Critical Geography. London; New York: Routledge.

Honig, B. (1998). Ruth, the Model Émigré: Mourning and the Symbolic Politics of Immigration. In P. Cheah (Ed.), Cosmopolitics: thinking and feeling beyond the nation (pp. 192-215). Minneapolis: University of Minnesota Press.

Iriye, A. (1970). Imperialism in East Asia. In J. B. Crowley (Ed.), Modern East Asia: Essays in Interpretation (pp. 135-50). New York: Harcourt, Brace \& World.

Kagami Mitsuyuki. Chūgoku no minzoku mondai: kiki no honshitsu (The national problem of China). Tokyo: Iwanami Shoten, 2008.

Kofman, E. (2005). Figures of the cosmopolitan. Innovation: The European Journal of Social Science Research 18(1): 83-97.

Kristeva, J. (1993). Nations without nationalism. New York: Columbia University Press. 
Lapid, Y. (2001). Rethinking the "International": IBO Clues for PostWestphalian Mazes. In M. Albert, D. Jacobson, \& Y. Lapid (Eds.), Identities, borders, orders?: rethinking international relations theory (pp. 23-28). Minneapolis: University of Minnesota Press.

Levenson, J. R. (1959). Liang Ch'i-Ch'ao and the Mind of Modern China. Cambridge, M.A.: Harvard University Press.

. (1971). Revolution and Cosmopolitanism: The Western Stage and the Chinese Stages. Berkeley: University of California Press.

Levy, D., \& Sznaider, N. (2007). Memories of Europe: cosmopolitanism and its others. In C. Rumford (Ed.), Cosmopolitanism and Europe (pp. 158177). Liverpool: Liverpool University Press.

Liang, Q. (1998). Liang Qichao xueshu lunzhu: Xianqin zhengzhi sixiang shi (Liang Qichao's academic writing: the history of political thoughts in the Pre-Qin period). Hangzhou: Zhejiang Renmin Chuban She.

- (2001). Yinbingshi wenji dianjiao (Collected writings from the Ice-Drinker's Studio, a proofread edition). Kunming: Yunnan Jiaoyu Chuban She.

- (2005). Yinbingshi heji, jiwaiwen (Collected writings from the Ice-Drinker's Studio, addendum), Beijing: Peking University Press, 2005.

Meinecke, F. (1970). Cosmopolitanism and the National State. Princeton, N.J.: Princeton University Press.

Mitchell, T. (2000). Introduction. In: Mitchell T (ed.) Questions of Modernity (pp. 11-27). Minneapolis: University of Minnesota Press.

Murata, Y. (1996). Nijyū seiki shisutemu toshite no chūgoku nashonarizumu' (Chinese nationalism as a twentieth-century system). In S. Nishimura (Ed.) Nashonarizumu: rekishi kara no sekkin (Chinese nationalism: institutional changes in Republican China). Tokyo: Tōkyō Daigaku Shuppan-kai.

O’Brien, K. (1997). Narratives of Enlightenment: Cosmopolitan History from Voltaire to Gibbon. New York: Cambridge University Press.

Rumford, C. (2007). Cosmopolitanism and Europe. Liverpool: Liverpool University Press.

Seth, S. (1995). Nationalism in/and Modernity. In J. Camilleri; A. Jarvis; A. Paolini (Ed.), The state in transition: reimagining political space (pp. 41-58). Boulder, Colo.: Lynne Rienner.

Sontag, S. (2002). Where the Stress Falls: Essays. London: Jonathan Cape.

Tanaka, S. (1993). Japan's Orient: Rendering Pasts into History. Berkeley: University of California Press.

Taylor, C. (1997). Nationalism and Modernity. In R. McKim \& J. McMahan (Ed.), The Morality of Nationalism (pp. 31-55). New York: Oxford University Press.

- (2001). Two theories of modernity. In D. P. Gaonkar (Ed.), Alternative modernities (pp. 172-196). Durham NC: Duke University Press.

Thomassen, B. (2010). Anthropology, multiple modernities and the axial age debate. Anthropological Theory, 10(4), 321-342.

Walker, R. B. J. (1993). Inside/outside: International relations as political theory. Cambridge [England]: Cambridge University Press.

Zhao, S. (2004). A nation-state by construction: dynamics of modern Chinese nationalism. Stanford, Calif, Stanford University Press.

Zou, R. ([1903]1956). Geming jun (Revolutionary army). In Zhongguo Shixue Hui (Ed.) Zhongguo jindaishi ziliao congkan: Xinhai geming, Vol. 1 (pp. 331-364). Shanghai: Shanghai Renmin Chuban She. 